\title{
The Effect of Lanthanides and Actinides on Blood Coagulation. II. Assay of a New Serum Thromboplastic Factor Vulnerable to These Elements and Its Vari- ations in Health and Disease *
}

\author{
Robert Colman and Benjamin Alexander \\ (From the Yamins Research Laboratory, Beth Israel Hospital, and the Department of Medicine, \\ Harvard Medical School, Boston, Mass.)
}

It has been previously reported $(1,2)$ that some rare earth and related elements progressively inactivate a hitherto unrecognized serum component necessary for thromboplastin generation. This factor (thorium vulnerable factor, TVF ${ }^{1}$ is distinct from any previously defined clotting factor or intermediate. It is adsorbable by $\mathrm{BaSO}_{4}$, eluted by citrate, precipitable from serum at 50 to $66 \%\left(\mathrm{NH}_{4}\right)_{2} \mathrm{SO}_{4}$ saturation, and separable from other coagulation constituents by physicochemical means. The thorium-induced inactivation is corrected by substituting normal platelets for phospholipid in the thromboplastin generating mixture. Inactivation can be completely reversed by citrate or oxalate, but not by extensive dialysis. TVF also differs from all known serum factors by its relative lability. This report includes an assay procedure, based on a modification of the thromboplastin generation test (TGT), the normal variation of TVF, and its levels in newborn infants, pregnant subjects, patients under coumarin therapy, and individuals with liver disease.

\section{Methods}

Thorium chloride ( $\mathrm{ThCl}_{4}$, chemically pure $)^{2}$ was analyzed as : rare earths, $0.03 \% ; \mathrm{Fe}, 0.01 \%$; and $\mathrm{Mg}, 0.01 \%$.

$\mathrm{BaSO}_{4}$-adsorbed oxalated plasma $\left(\mathrm{BaSO}_{4}\right.$ plasma) was prepared by mixing fresh oxalated human plasma with $100 \mathrm{mg} \mathrm{BaSO}_{4}$ (chemically pure) ${ }^{3}$ per $\mathrm{ml}$ for $15 \mathrm{~min}$ utes at $25^{\circ} \mathrm{C}$

* Submitted for publication June 4, 1963 ; accepted December 12, 1963.

Supported by U. S. Public Health Service grant HE00656.

1 Terminology selected temporarily until further study permits biochemical or physiological designation.

2 Amend Drug \& Chemical Co., New York, N. Y.

${ }^{3}$ J. T. Baker Chemical Co., Phillipsburg, N. J.
Serum was obtained in the usual manner from fresh venous blood and permitted to remain clotted in a glass tube for 2 hours at room temperature until used. For purposes described below, sera obtained from 14 subjects (ages, 5 to $81 ; 9$ females and 5 males) who had no demonstrable liver disease, who had not received anticoagulants or salicylates, and who were not pregnant, were pooled, and the pool was divided into suitable samples which were maintained at approximately $-12^{\circ} \mathrm{C}$ until used. The material, arbitrarily assumed normal, was considered to contain $100 \%$ of each clotting factor.

Thorium-treated serum (TTS). $0.3 \mathrm{ml}$ of $0.01 \mathrm{M}$ $\mathrm{ThCl}_{4}$ was gradually (over 5 minutes) added with constant stirring to $20 \mathrm{ml}$ of pooled normal serum (final thorium concentration, $1.5 \times 10^{-4} \mathrm{M}$ ). After an additional 5 minutes of stirring, the mixture was incubated for 4 hours at $37^{\circ} \mathrm{C}, 4$ and thereafter maintained frozen in subdivided samples at $-12^{\circ} \mathrm{C}$.

Factor IX [plasma thromboplastic component (PTC)]deficient serum 5 was obtained from patients with verified heredofamilial Factor IX deficiency.

Factor $X$ (Stuart Factor)-deficient serum was similarly derived from an individual with deficiency in this factor. ${ }^{6}$

Factor XI [plasma thromboplastic antecedent (PTA)]deficient serum was obtained from a subject with this respective deficiency. The defect was confirmed by crossmatching corrective experiments with serum from the original Factor XI-deficient patient of Rosenthal, Dreskin, and Rosenthal (5).

Factor XII (Hageman Factor)-deficient serum, from the original patient described by Ratnoff and Colopy (6), was kindly provided by Dr. John Graham of the University of North Carolina.

\footnotetext{
4 Under these conditions, and in the absence of thorium, substantial deterioration in TVF occurs (2).

5 Nomenclature is in accordance with recommendations of the International Committee on Blood Coagulation Factors (3).

6 This serum, kindly provided by Dr. Samuel Dorantes of the Children's Hospital, Mexico City, failed to correct the clotting defect of serum from the original patient of Hougie, Barrow, and Graham (4) with Factor $\mathrm{X}$ deficiency.
} 
Factor VIII (antihemophilic factor)-deficient plasma (oxalated) was obtained fresh from a patient with classical hemophila, then adsorbed with $\mathrm{BaSO}_{4}{ }^{3}$ (100 mg per $\mathrm{ml}$ ), and used promptly.

Factor $V$ (proaccelerin)-deficient plasma. Normal oxalated plasma was permitted to age at 0 to $4^{\circ} \mathrm{C}$ for 1 week, and then adsorbed with $\mathrm{BaSO}_{4}$.

Veronal buffered isotonic saline (VBIS) and Inosithin 7 solution were prepared as previously described (7). The latter was stored in suitable samples at $-12^{\circ} \mathrm{C}$ until used.

Thromboplastin generation test (TGT). This was performed according to the method of Biggs and Douglas (8), modified by substituting Inosithin for platelets, and $\mathrm{BaSO}_{4}$ for $\mathrm{Al}(\mathrm{OH})_{3}$ for plasma adsorption. A mixture comprising $0.50 \mathrm{ml}$ of Inosithin solution, $0.10 \mathrm{ml}$ of $\mathrm{BaSO}_{4}$-adsorbed plasma diluted with $0.40 \mathrm{ml}$ VBIS, and $0.05 \mathrm{ml}$ of serum diluted with $0.45 \mathrm{ml}$ VBIS (total volume of mixture, $1.5 \mathrm{ml}$ ) was brought to $37^{\circ} \mathrm{C}$, and $0.5 \mathrm{ml}$ of $0.025 \mathrm{M}$ calcium chloride was added. A stop watch was started, and at selected intervals $0.20-\mathrm{ml}$ samples of the mixture were blown into $0.10 \mathrm{ml}$ of plateletpoor plasma contained in another test tube kept at $37^{\circ} \mathrm{C}$. The clotting times were recorded and plotted against the incubation times of the thromboplastin generating mixture. Observations were continued for at least 2 minutes beyond the minimal observed clotting time to ascertain the maximal velocity of coagulation.

With respect to TVF, the TGT was performed as follows: instead of the usual $0.05 \mathrm{ml}$ of normal serum, a combination of normal serum with TTS was used, each added separately in $0.025-\mathrm{ml}$ amounts to the incubation mixture.

To obtain a reference curve of TVF concentration, pooled normal serum, arbitrarily considered to contain $100 \%$ of all the factors, was suitably diluted with VBIS to give concentrations of $50,25,10,5,1$, and $0.5 \%$ of normal serum, respectively. $0.025 \mathrm{ml}$ of each dilution was admixed in the thromboplastin incubation mixture (containing adsorbed normal plasma) with $0.025 \mathrm{ml}$ of the TTS. A TGT was thus obtained for each dilution of normal serum combined with the TTS. The minimal clotting time (Cl.T.) of the platelet-poor plasma obtained for each combination and the corresponding incubation time (In.T.) were recorded. The arithmetic product of the two (Cl.T. X In.T.) was calculated (Figure $1 \mathrm{~A}$ ), and the product was plotted against the logarithm of the concentration of the normal serum used in the test (Figure 1B). This product reflects the corrective effect of variable amounts of normal serum containing TVF on the poor TGT obtained with an incubation mixture containing TVF-deficient serum and devoid of normal serum. The system containing the deficient serum is considered normal in all thromboplastin generating factors other than TVF.

By interpolation on a curve such as that in Figure 1B, an unknown serum or fraction can be assayed in terms of the $100 \%$ activity of normal serum.

\footnotetext{
? Inositol phospholipid, Associated Concentrates Co.,
} Woodside, N. Y.
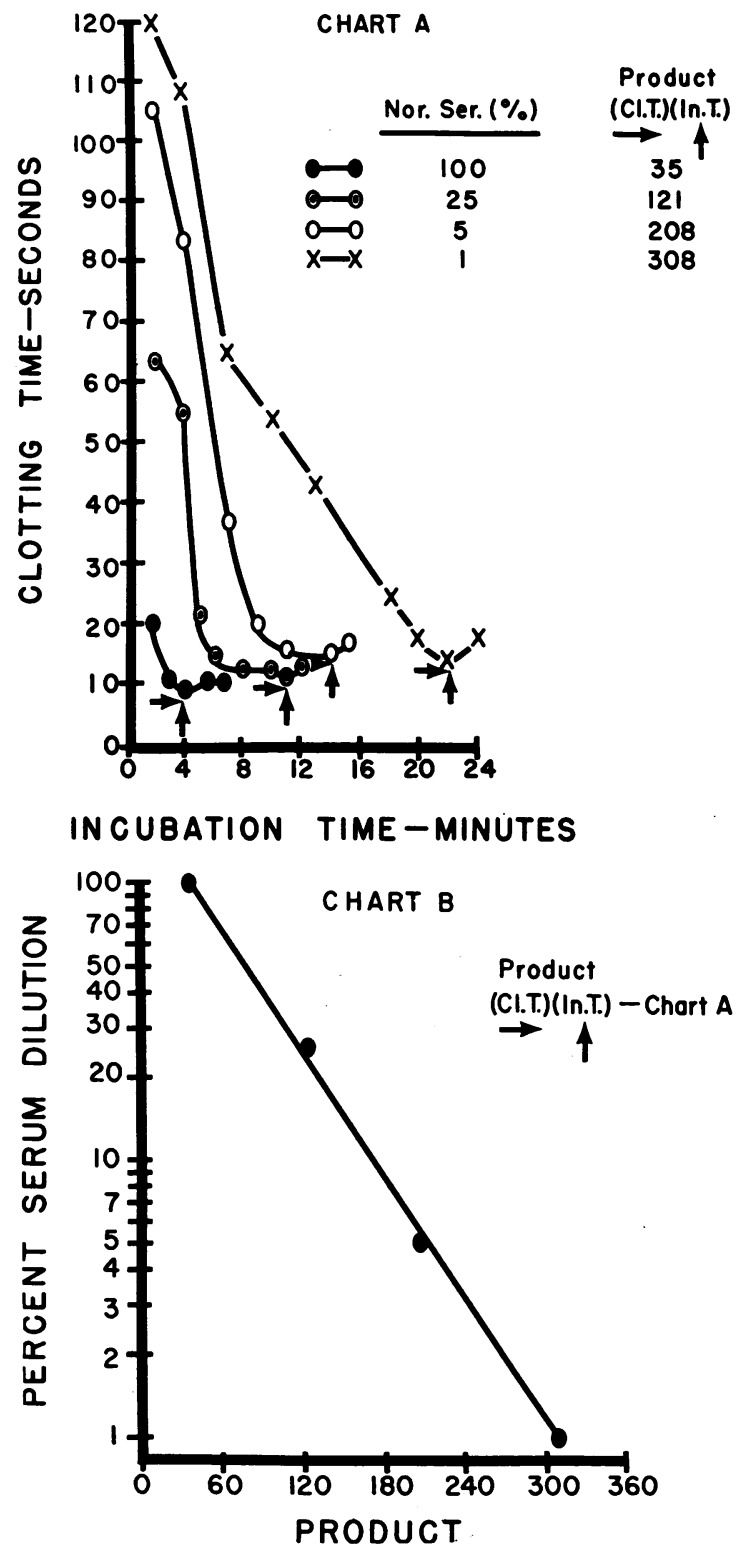

Fig. 1A. Thromboplastin generation test (TGT) WITH TVF-DEFICIENT SERUM. The ingredients comprised: $0.85 \mathrm{ml}$ Veronal buffered isotonic saline (VBIS), $0.05 \mathrm{ml} \mathrm{BaSO}$-adsorbed normal oxalated plasma, 0.025 $\mathrm{ml}$ thorium-treated serum (TTS) (undiluted), and 0.025 $\mathrm{ml}$ normal serum variously diluted, e.g., $25 \%$ (column 1 ) indicates that the normal serum was diluted 1 to 4 with VBIS before addition of $0.025 \mathrm{ml}$ to the incubation mixture. Inosithin $(0.5 \mathrm{ml})$ and $\mathrm{Ca}^{++}(0.5 \mathrm{ml})$ were subsequently added in the usual manner.

B. Semilog Plot of arith METIC PRODUCTS OF MiNIMAL Clotting time (Cl.T.) OF the CLOTting SUbStrate (PLATELET-POOR PLASMA) AND THE INCUBATION TIMES (IN.T.) OF THE THROMBOPLASTIN GENERATING MIXTURES CONTAINING TTS AND VARIABLE AMOUNTS OF NORMAL SERUM. 


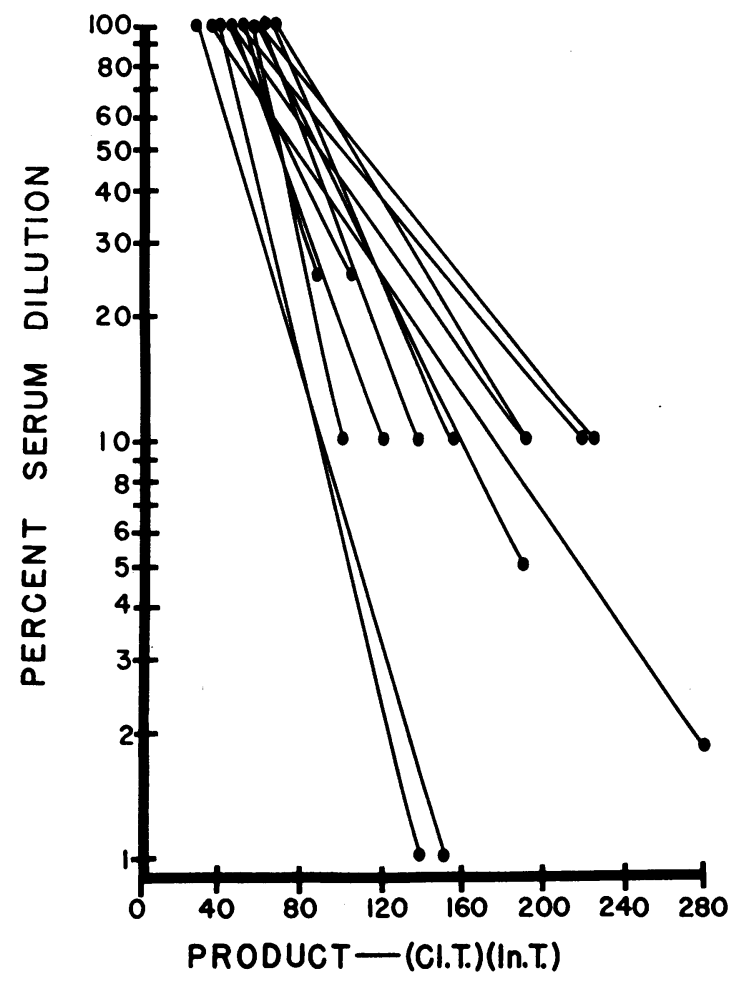

Fig. 2. EXAMPLES OF INDIVIDUAL THORIUM VULNERABLE FACTOR (TVF) ASSAY CURVES OBTAINED WITH A SINGLE POOLED NORMAL SERUM. The TTS was derived from the same single pooled serum. For simplicity, only 14 of 30 curves are shown, covering the broadest range. Also omitted are individual points for each curve; their deviations from their respective composite lines were, as in Figure 1B, insignificant.

Prothrombin time. One-stage procedure of Quick (9), with human brain thromboplastin, was used.

Factor $V$ (proaccelerin), Factor VII activity, and Factor II (prothrombin) determination. These factors were assayed by the method of Owren and Aas (10), using for each a reagent plasma deficient in the factor measured. Factor VII activity reflects the concentrations of both Factors VII (proconvertin) and X (Stuart Factor).

Factor $X$ was measured by the procedure of Bachman, Duckert, and Koller (11).

Clotting time was measured by the Lee-White procedure, using three clotting tubes. The clotting time observed in the third tube was considered the end-point.

Prothrombin consumption was performed by the method of Graham, McLendon, and Brinkhous (12).

Platelets were enumerated by the Ham procedure (13), using Rees-Ecker dilution fluid. In our laboratory the normal range is 200,000 to 400,000 per $\mathrm{mm}^{3}$.

Normal subjects. Fourteen consecutive individuals, at the Outpatient Clinic, comprising nine females and five males (ages, 5 to 81 ), were selected as "normal." None had a history of liver disease or were pregnant, nor were they receiving coumarins or salicylates.

Nezuborn infants. Blood was obtained at birth from the umbilical cords of eight; the mothers had not received Vitamin $\mathrm{K}$.

Coumarin-treated patients. Individuals were selected who had received warfarin or Dicumarol for 2 to 17 days (short term) and for more than 1 month (long term). All patients had a Quick plasma prothrombin activity of $20 \%$ or less.

Liver disease. Patients were selected with known hepatocellular disease, confirmed by biopsy in most. In all instances, liver function tests were abnormal, and the plasma prothrombin activities were less than $65 \%$. The diagnoses were alcoholic cirrhosis in six, infectious hepatitis in one, and Wilson's disease in one. One subject with cirrhosis was studied before and after transfusion.

Pregnant patients. Sixteen subjects were studied who were 10 to 43 weeks pregnant and between 16 and 35 years of age.

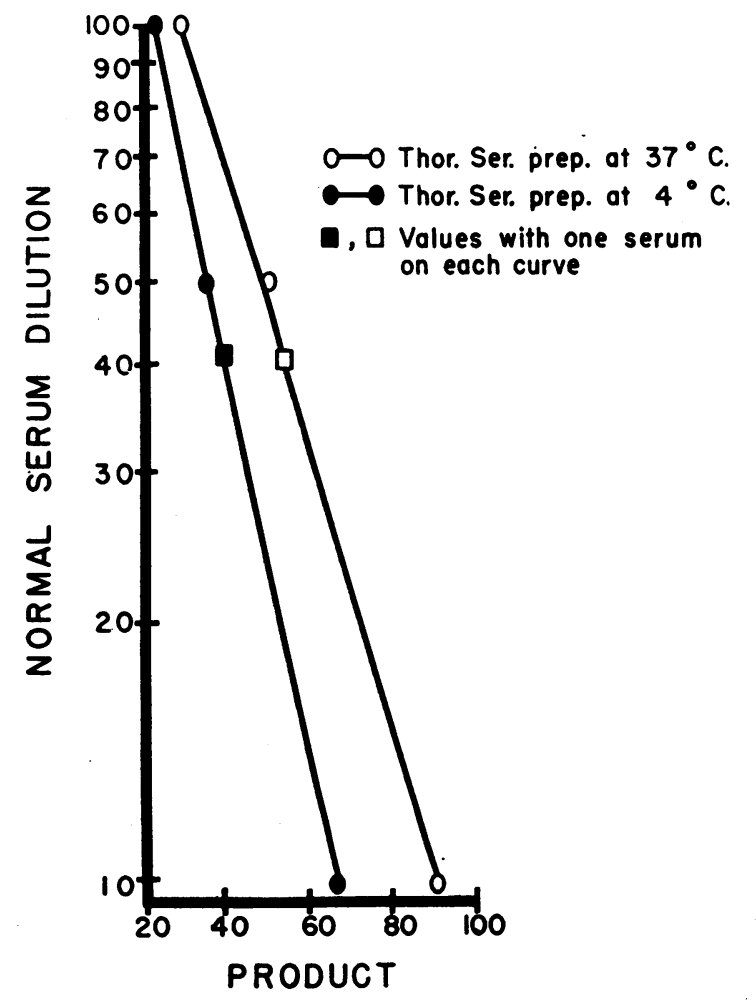

Fig. 3. Two TVF assay curves obtained with VARIOUS DILUTIONS OF A SINGLE NORMAL SERUM ADMIXED IN THE TGT WITH EACH OF TWO THORIUM-TREATED SERA. One was prepared at $37^{\circ} \mathrm{C}$ and the other at $4^{\circ} \mathrm{C}$. The same normal serum, deliberately rendered TVF deficient by incubating at $37^{\circ} \mathrm{C}$ for several hours, was then assayed concurrently with each TTS and interpolated on the two respective assay curves. The TVF values are designated by the squares. 


\section{Results}

Thorium vulnerable factor $(T V F)$. Thirty individual assay curves were obtained on a single pool of serum derived from 14 normal subjects. The Cl.T. $\times$ In.T. product obtained with a combination of TTS and diluted normal serum was plotted against the logarithm of the concentration of normal serum in the incubation mixture. In each instance a rectilinear correlation was obtained over a range of 1 to $100 \%$ concentration (Figure 2).

Since in all these experiments the same pool provided both the normal serum and the TTS, the only evident variables consisted of the absorbed normal plasma ${ }^{8}$ and, from time to time, the Inosithin and platelet-poor plasma (the clotting substrate). As evident in Figure 2, the curves are remarkably parallel, the deviations probably being referable to these variables. Although the standard curve is generally reproducible from day to day, because of occasional variation it is desirable to have a new curve for each series of assays.

In thus quantitating TVF in an unknown serum, the total extent of the thorium-induced

8 This varied from time to time over the interval during which the 30 curves were obtained, and the material was either fresh or maintained frozen for 2 weeks or less. defect in the TTS is evidently not a variable of great significance. This is apparent from the following experiment: standard curves were derived with TTS prepared from the same serum at $4^{\circ}$ and $37^{\circ} \mathrm{C}$. The slopes of the two curves were slightly different (Figure 3 ). When, however, a sample of normal serum that was exposed to $37^{\circ} \mathrm{C}$ for 4 hours to induce considerable TVF deficiency (2) was assayed by interpolation on both of these curves, the results were essentially the same (41 and 42\% TVF activity) (Figure $3)$.

In one experiment the TVF of sera deficient in Factors IX, X, and XI contained 108, 93, and $105 \%$, respectively. In two other Factor IXdeficient subjects and one additional Factor Xdeficient subject, TVF was also normal.

Table I summarizes many of the results. The range of TVF in the normal subjects (62 to $144 \%$; mean, $103 \%$; SE, $31 \%$ ) is similar to that reported for other factors (14). Although the number of subjects is too small to permit valid statistical evaluation, from the lower tail of the distribution curve it appears that a value less than $52 \%$ occurs in less than $5 \%$ of normal individuals.

Newborns were the most severely affected, showing a mean of $26 \%$ with a SD of $13 \%$. By the $t$ test, the difference between the means of

TABLE I

Clinical studies on thorium vulnerable factor (TVF)

\begin{tabular}{|c|c|c|c|c|}
\hline Subjects & Number & $\underset{\text { Mean } \% \text { SD }}{\text { TVF }}$ & $t$ test & Remarks \\
\hline Normal & 14 & $\begin{array}{c}\% \\
103.0 \pm 31.0\end{array}$ & & $\begin{array}{l}5 \text { males, } 9 \text { females } \\
\text { Ages, } 5-81 \text { yrs }\end{array}$ \\
\hline Newborn & 8 & $25.5 \pm 13.2$ & $\mathrm{p}<.001$ & $\begin{array}{l}\text { Cord blood } \\
\text { No vitamin } K\end{array}$ \\
\hline Coumarin treated & 20 & $31.5 \pm 15.0$ & $\mathrm{p}<.001$ & $\begin{array}{l}\text { Dicumarol, warfarin } \\
2 \text { days }-6 \text { months } \\
\text { Quick value }<20 \%\end{array}$ \\
\hline Liver disease & 8 & $33.0 \pm 11.6$ & $\mathrm{p}<.001$ & $\begin{array}{l}\text { Diagnoses: alcoholic } \\
\text { cirrhosis, } 6 \text {; infectious } \\
\text { hepatitis, } 1 \text {; Wilson's } \\
\text { disease } 1 \\
\text { Quick time }<65 \%\end{array}$ \\
\hline Pregnant & 16 & $82.0 \pm 25.0$ & $\mathrm{p}>.05$ & $\begin{array}{l}\text { 19-43 weeks } \\
\text { Ages, 16-35 yrs } \\
\text { Factors VII and X } \\
\quad \text { elevated }\end{array}$ \\
\hline
\end{tabular}




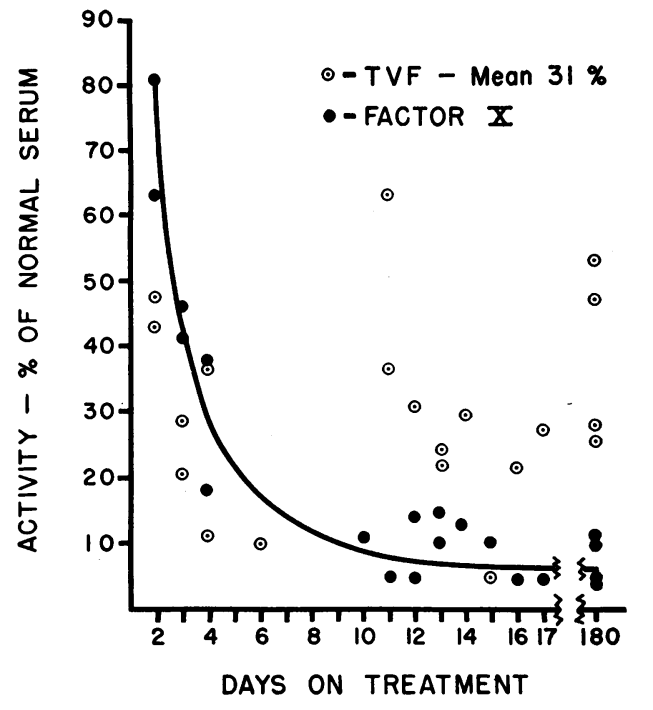

Fig. 4. TVF AND Factor $X$ LEVELS IN COUMARINTREATED SUBJECTS. Paired observations (TVF and X) were made on the same sera from different individuals. Individualization of pairs was omitted for simplicity. Most of the patients were receiving Dicumarol, others warfarin, for intervals indicated.

newborn and normal groups seemed significant at a level of less than 0.001 . The range was 8 to $50 \%$, indicating little if any overlap with the normal range.

TVF is also significantly low in the serum of coumarin-treated patients (Figure 4). The difference between the means of the treated and normal subjects is significant at a $p$ level of less than 0.001 . Factor $\mathrm{X}$ levels, generally not greatly reduced till after day 5 on the drugs, did not correlate with TVF activity. In contrast to Factor X, TVF levels were generally less than $50 \%$ after the second day. Thereafter, and apparently unrelated to duration of drug therapy, they fluctuated about a mean level of $31 \%$ while the mean Factor X activity was $10 \%$.

Since under coumarin therapy TVF appeared to decline more rapidly than Factor X, an experiment was undertaken to assess the response of various coumarin-sensitive clotting factors during the first 40 hours following the drug. Warfarin $(0.5 \mathrm{mg}$ per $\mathrm{kg})$ was voluntarily ingested by a 35-year-old normal male (L.P.), and at selected intervals thereafter Factors II, VII, X, and TVF were measured. The results (Figure 5) indicate that Factor II declined early and only slightly; Factor VII decreased quite promptly and pro- foundly, as did TVF, also. The last to decrease was Factor $\mathrm{X}$. The time lapse required to reach $50 \%$ of the original levels was approximately 17 hours for Factor VII, 24 hours for TVF, and 34 hours for Factor X. After 40 hours, when the one-stage prothrombic activity was $17 \%$, Factor VII activity was $17 \%$, TVF was $20 \%$, Factor X was $35 \%$, and Factor II was $79 \%$.

The TVF of patients with severe liver disease was uniformly depressed (Table I). The mean (33\%) differed profoundly from the normal ( $\mathrm{p}$ $<0.001$ ), and the range (13 to 50\%) did not overlap significantly with the normal. Table II summarizes several other coagulation parameters. The severity of the TVF depression paralleled the others, but no strict correlation was observed with any one factor. Usually TVF was more severely depressed than Factors II or VII-X, and frequently to the same extent or even lower than Factor V.

Patient Mi (Table II) was studied before, and 48 hours after, transfusion with $2 \mathrm{U}$ of bank blood. This was followed by a rise in the onestage prothrombic activity, probably a reflection of the rise in Factors VII-X and II. However, Factor $\dot{V}$ and TVF did not increase significantly. This may be due to the fact that owing to their lability, both these factors may have

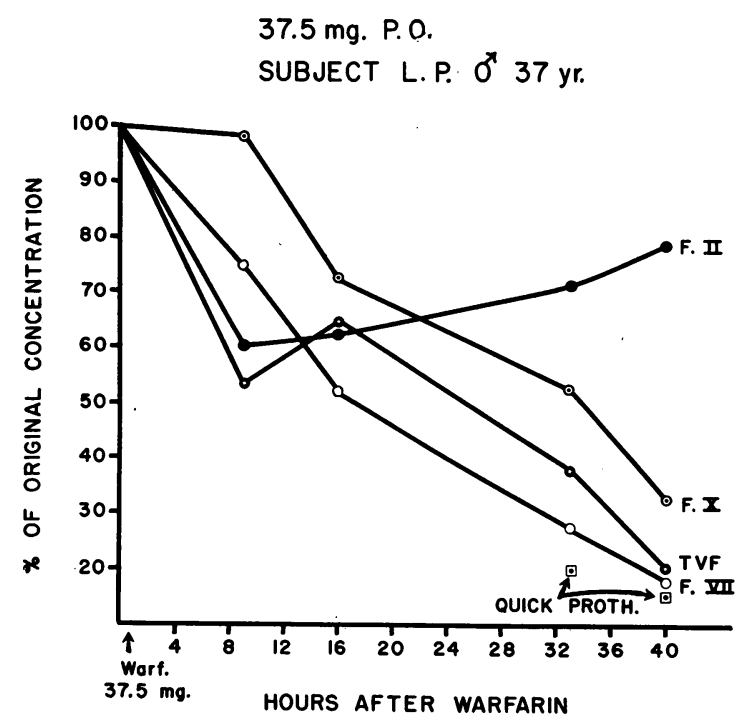

Fig. 5. Sequential efFect of Warfarin on TVF AND OTHER COUMARIN VULNERABLE FACTORS. Dotted squares indicate the whole plasma prothrombic activity (9). 
TABLE II

Summary of coagulation parameters

\begin{tabular}{|c|c|c|c|c|c|c|c|c|c|c|c|}
\hline Patient & Sex & Diagnosis & $\begin{array}{c}\text { Quick } \\
\text { pro- } \\
\text { throm- } \\
\text { bin } \\
\text { activ- } \\
\text { ity }\end{array}$ & $\underset{\mathrm{V}}{\text { Factor }}$ & $\begin{array}{c}\text { Factor } \\
\text { II }\end{array}$ & $\begin{array}{l}\text { Factors } \\
\text { VII-X }\end{array}$ & TVF & $\begin{array}{l}\text { Clot- } \\
\text { ting } \\
\text { time }\end{array}$ & $\begin{array}{l}\text { Residual } \\
\text { serum } \\
\text { pro-- } \\
\text { throm- } \\
\text { bin }\end{array}$ & $\begin{array}{c}\text { Clot } \\
\text { retrac- } \\
\text { tion }\end{array}$ & $\begin{array}{l}\text { Platelet } \\
\text { count }\end{array}$ \\
\hline & & & $\%$ & \multicolumn{3}{|c|}{ Owren, \% } & $\%$ & $\min$ & $\%$ & & $/ m^{3}$ \\
\hline \multirow{2}{*}{$\begin{array}{l}\mathrm{Li} \\
\mathrm{Mi} \\
\mathrm{Mi}\end{array}$} & \multirow{2}{*}{$\begin{array}{l}\mathrm{M} \\
\mathrm{F} \\
\mathrm{F}\end{array}$} & \multirow{2}{*}{$\begin{array}{l}\text { Alcoholic cirrhosis } \\
\text { Alcoholic cirrhosis } \\
\text { Alcoholic cirrhosis } \\
\text { (posttransfusion) }\end{array}$} & $\begin{array}{l}20 \\
34\end{array}$ & $\begin{array}{l}32 \\
32\end{array}$ & $\begin{array}{l}35 \\
55\end{array}$ & $\begin{array}{l}47 \\
42\end{array}$ & $\begin{array}{l}22 \\
50\end{array}$ & 10 & 10 & $\begin{array}{l}\text { Good } \\
\text { Good }\end{array}$ & $\begin{array}{r}86,000 \\
186,000\end{array}$ \\
\hline & & & 58 & 38 & 69 & 76 & 44 & 11 & 10 & Good & \\
\hline $\mathrm{Ki}^{*}$ & $\mathrm{~F}$ & Alcoholic cirrhosis & 55 & 47 & 52 & 57 & 35 & 12 & & Good & \\
\hline $\mathrm{Fa}$ & $\mathbf{M}$ & Infectious hepatitis & 30 & & & & 30 & 10 & $<10$ & Good & \\
\hline $\mathrm{Ba}$ & $\mathbf{M}$ & Wilson's disease & 45 & 53 & 25 & 50 & 13 & & & & \\
\hline $\mathrm{Fi}$ & $\mathrm{F}$ & Alcoholic cirrhosis & 60 & 53 & 78 & 53 & 34 & & & & \\
\hline $\mathrm{Re}^{*}$ & $\mathbf{M}$ & Alcoholic cirrhosis & 40 & & & & 36 & 10 & & Good & 160,000 \\
\hline
\end{tabular}

* Patients from Boston City Hospital; others from Beth Israel Hospital, Boston, Mass.

been greatly reduced initially in the transfused blood, or because their in vivo survival is shorter than that of Factors VII, X, or II.

In accord with earlier reports $(15,16)$, the pregnant subjects had elevated Factors VII-X (Figure 6). This consistent abnormality appeared unrelated to the length of gestation. In contrast, TVF levels were essentially normal.

\section{Discussion}

To explore the properties of the clotting factor required for thromboplastin formation that is uniquely vulnerable to the rare earth and related elements, an assay procedure was designed. As with many reported methods for measuring thromboplastin generating factors, the general principle was based upon the corrective (or lack of corrective) effects of serum or fractions thereof, compared with normal serum, on the defective TGT of a system solely and specifically deficient in this entity (TVF). The method described is believed to meet this rigorous requirement. Prior treatment of normal serum with thorium provides the basic material for the defective system. The clot corrective effects of variable dilutions of normal serum combined with this defective serum provide the standard reference curve on which the effect of the unknown is interpolated, yielding a quantitative value in terms of normal serum.

The rectilinear correlation between the arithmetic product of the clotting time and the incubation time of the thromboplastin generating mixture with the logarithm of the concentration of normal serum in the mixture permits simple and reasonably accurate interpolation. Unfortunately, this empiric relationship, observed also for Factors I, VIII, IX, XI, and XII (17), could not be expressed mathematically or explained by known biochemical interactions.

TVF is significantly depressed in newborn infants, in patients with liver disease, and in coumarin-treated subjects. After warfarin ingestion, it declines rapidly. In these respects, it resembles the coumarin-sensitive vitamin $\mathrm{K}$-dependent factors (II, VII, IX, and X), yet many data in this and the preceding report (2) distinguish TVF

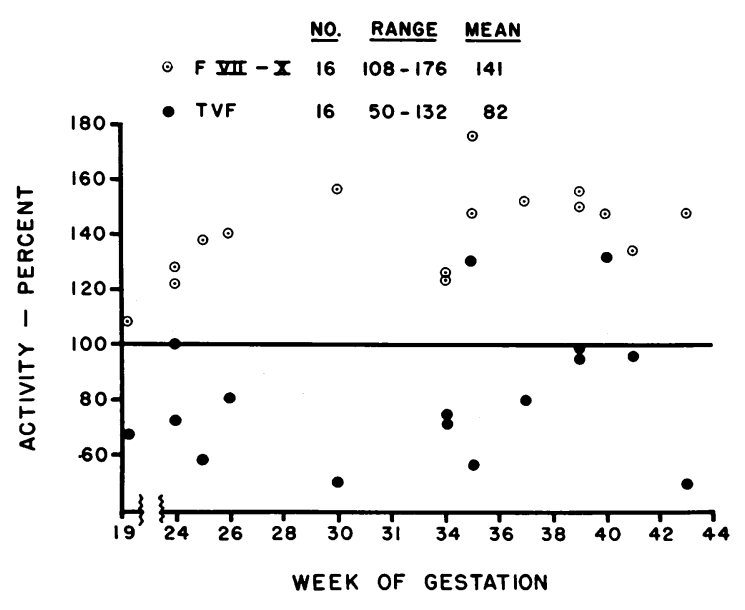

Fig. 6. Factors VII-X ACtivity (PLASMa) AND TVF (SERUM) In PREgnancy. As in Figure 4, TVF and Factors VII-X activity were determined on the same bloods, but designation of the individual pairs is omitted. 
from other entities. Unlike them, TVF is relatively unstable, and unlike Factors VII to X, it is normal in the gravid.

There is some evidence for the existence of coagulation thromboplastin generating entities distinct from those already defined. Rabiner and Spaet (18) noted that serum aged at room temperature for 24 to 72 hours or kept at $37^{\circ} \mathrm{C}$ for several hours failed to correct the defective thromboplastin generation of patients with liver disease, whereas sera deficient in Factors IX or $\mathrm{X}$ were corrective. Seaman and Karlsen (19) could correct this labile serum defect also with platelets. Similarly, Connor, Warner, and Carter (20) observed that the sera of newborns, of patients with liver disease, and of coumarin-treated subjects could not support thromboplastin generation after incubation at $37^{\circ} \mathrm{C}$ for 3 to 24 hours. Again, this abnormality could be rectified by fresh serum, by Factor IX- or Factor X-deficient serum, and by platelets, but not by $\mathrm{BaSO}_{4}^{-}$ adsorbed plasma or serum.

It thus appears that normal serum contains an entity, first described by Duckert, Fluckiger, and Koller (21), which is labile and distinct from Factors IX and X. Possibly TVF is identical with this factor. Moreover, TVF is clearly depressed in three distinctly different clinical states.

It is now agreed (22) that the order in which the coagulation factors decrease after coumarin drugs is Factor VII, followed by Factors X, II, and IX. Sise, Lavelle, Adamis, and Becker (23) have shown that after $300 \mathrm{mg}$ of intravenous warfarin Factor VII declines by day 2, but Factor $\mathrm{X}$ does not reach $20 \%$ until day 5. At this point, Factor II may be as high as $35 \%$. In our investigation, the order of depression of Factors VII, X, and II agreed well with earlier observations. Factor VII activity was less than $20 \%$ by 40 hours, but Factor $\mathrm{X}$ did not attain this level until at least day 4. TVF declines more slowly than Factor VII but more rapidly than Factor X, reaching $20 \%$ by 40 hours. In contrast, Factor IX becomes depressed only after 1 week of coumarin therapy. This dissociation between TVF and the other coumarin-susceptible factors is also in accord with the conclusion that TVF is distinct.

In liver disease, however, TVF is usually more affected than Factors VII, X, or II-more akin to Factor V. Sherlock (24) postulated that diminished protein synthesis and impaired vita$\min \mathrm{K}$ absorption associated with hepatic disorders lead to low levels of clotting components. The dissociation of protein synthesis from vitamin $\mathrm{K}$ provision is exemplified in the instance of Factor V, which is low in liver disease but normal in K-deficiency and during coumarin therapy. TVF, apparently affected by coumarin congeners as well as by liver disease, seems particularly sensitive to the latter and presumably to disordered protein synthesis.

Dissociation between TVF and Factors VII, IX, and $\mathrm{X}$ is also clearly evident in pregnancy. This investigation confirms earlier observations $(15,16)$ that both Factors VII and X are increased in the gravid. Similarly, Factor IX is strikingly elevated (25). In contrast, TVF is normal. These data also supported the conclusion that TVF is distinct. All the distinguishing features are summarized in Table I.

\section{Summary}

1) An assay procedure for measuring the thorium (and related elements) vulnerable factor is described. The range of this clotting factor was defined in 14 normal subjects.

2) Thorium vulnerable factor is markedly depressed in newborn infants.

3) After ingestion of coumarin derivatives it declines at rates and attains levels that do not correlate with Factors II, VII, or X.

4) In severe liver disease, levels of the thorium vulnerable factor are low, corresponding in degree to Factor V.

5) In contrast to Factors VII, IX, and X, the factor is not elevated in the gravid.

6) These findings provide additional evidence that the thorium vulnerable entity is a hitherto unrecognized serum factor necessary for thromboplastin generation.

\section{References}

1. Alexander, B., and R. Colman. Evidence for a new serum thromboplastic factor. Thrombos. Diathes. haemorrh. (Stuttg.) 1959, 4 (suppl.), 66.

2. Alexander, B., and R. Colman. The effect of lanthanides and actinides on blood coagulation. I. Evidence for and properties of a new serum 
thromboplastic factor. J. clin. Invest. 1964, 43, 705.

3. Progress in coagulation. Thrombos. Diathes. haemorrh. (Stuttg.) 1962, 7 (suppl.), 379.

4. Hougie, C., E. M. Barrow, and J. B. Graham. Stuart clotting defect. I. Segregation of an hereditary hemorrhagic state from the heterogeneous group heretofore called "stable factor" (SPCA, proconvertin, factor VII) deficiency. J. clin. Invest. 1957, 36, 485.

5. Rosenthal, R. L., O. H. Dreskin, and N. Rosenthal. New hemophilia-like disease caused by the deficiency of third plasma thromboplastin factor. Proc. Soc. exp. Biol. (N. Y.) 1953, 82, 71.

6. Ratnoff, O. D., and J. E. Colopy. A familial hemorrhagic trait associated with a deficiency of clotpromoting fraction of plasma. J. clin. Invest. 1955, 34, 602 .

7. Tishkoff, G. H., L. Pechet, and B. Alexander. Some biochemical and electrophoretic studies on purified prothrombin, factor VII (proconvertin) and factor X (Stuart). Blood 1960, 15, 778.

8. Biggs, R., and A. S. Douglas. Thromboplastin generation test. J. clin. Path. 1963, 6, 23.

9. Quick, A. J. The clinical application of the hippuric acid and prothrombin tests. Amer. J. clin. Path. 1940, 10, 222.

10. Owren, P. A., and K. Aas. The control of Dicumarol therapy and the quantitative determination of prothrombin and proconvertin. Scand. J. clin. Lab. Invest. 1951, 3, 201.

11. Bachman, F., F. Duckert, and F. Koller. StuartPrower factor assay and its clinical significance. Thrombos. Diathes. haemorrh. (Stuttg.) 1958, 2, 24.

12. Graham, J. B., W. W. McLendon, and K. M. Brinkhous. Mild hemophilia: An allelic form of the disease. Amer. J. med. Sci. 1953, 225, 46.

13. Ham, T. H. A Syllabus of Laboratory Examination in Clinical Diagnosis; Critical Evaluation of Laboratory Procedures in the Study of Patients. Cambridge, Mass., Harvard University Press, 1950.
14. Rapaport, S. I., R. B. Proctor, M. J. Patch, and M. Yettra. The mode of inheritance of PTA deficiency: evidence for the existence of major PTA deficiency and minor PTA deficiency. Blood 1961, 18, 149.

15. Pechet, L., and B. Alexander. Increased clotting factors in pregnancy. New Engl. J. Med. 1961, 265, 1093.

16. Alexander, B., L. Meyers, J. Kenny, R. Goldstein, V. Gurewich, and L. Grinspoon. Blood coagulation in pregnancy. Proconvertin and prothrombin, and the hypercoagulable state. New Engl. J. Med. 1956, 254, 358.

17. Colman, R., and B. Alexander. Unpublished observations.

18. Rabiner, S. F., and T. H. Spaet. Thromboplastin generation as a test of liver function. Amer. J. med. Sci. 1959, 238, 280.

19. Seaman, A. J., and K. M. Karlsen. Influence of serum incubation conditions on asolectin thromboplastin generation results. Thrombos. Diathes. haemorrh. (Stuttg.) 1960, 4, 83.

20. Connor, W. E., E. D. Warner, and J. R. Carter. A labile serum factor clotting defect: its demonstration by the thromboplastin generation test and its clinical significance. J. clin. Invest. 1961, 40, 13.

21. Duckert, F., P. Fluckiger, and F. Koller. Le rôle du Facteur X dans le formation de la thromboplastine sanguine. Rev. Hémat. 1954, 9, 489.

22. Alexander, B., and S. Wessler. A guide to anticoagulant therapy. Circulation 1961, 24, 123.

23. Sise, H. S., S. M. Lavelle, D. Adamis, and R. Becker. Relation of hemorrhage and thrombosis to prothrombin during treatment with coumarin-type anti-coagulants. New Engl. J. Med. 1958, 259, 266.

24. Sherlock, S. Symposium on Anticoagulant Therapy, G. W. Pickering, Ed. London, Harvey and Blythe, 1961.

25. Ratnoff, O. D., and T. R. Holland. Coagulation components in normal and abnormal pregnancies. Ann. N. Y. Acad. Sci. 1959, 75, 626. 